\title{
Digestion and absorption of nutrients in growing pigs
}

\author{
By A. G. Low, National Institute for Research in Dairying, Shinfield, Reading \\ $R G 2$ gAT
}

\section{Introduction}

Although digestion, the process of reducing the size of organic molecules by hydrolysis, is distinct from absorption, the process of uptake of molecules and ions by the epithelial cells lining the gut, experimental methods usually only give a measure of the combined process, called the digestibility of a nutrient. This term is not only a measure of $(r)$ the susceptibility of the physical and chemical structure of the nutrient to hydrolysis, but also of (2) the capacity of the animal to secrete sufficient enzymes of the appropriate type to effect the hydrolysis, in the presence of a suitable mineral solution, and of $(3)$ the ability of the absorptive system to remove the nutrient from the gut lumen. In view of the fact that digestibility values do not necessarily correlate well with other nutritional indices, e.g. retention, and because of the desire to improve the efficiency of feed utilization, there is considerable interest in understanding the detailed processes of digestion and absorption. This account attempts to outline the present state of knowledge of this subject in growing pigs. Emphasis is given only to digestibility values measured in faeces where these may be directly compared with measurements proximal to the rectum. The digestibilities of many feeding-stuffs have been published by the (US) National Research Council (1969).

\section{Methodology}

Serial slaughter has been the most widely used method for study of the gut in pigs, since it is simple and allows simultaneous measurements to be made in the whole organ. However, only one measurement per pig is possible, and a large number of pigs are needed to study the effects of time after feeding. A disadvantage of this method is the extensive shedding of mucosal cells into the lumen of the intestine at the time of slaughter, which has been found in sheep by Badawy (1964). Indirect evidence that this occurs in pigs also was given by Horszczaruk (1971b,c), who found far more nitrogen (and substantially more of other nutrients) in the intestine of slaughtered pigs than in that of pigs with cannulas, as measured by chromic oxide:nutrient ratios.

Surgical introduction of cannulas into the gut using the method of Crocker \& Markowitz (1936) allows continuous sampling of digesta from conscious animals over periods of months. The use of simple cannulas, which allow 'spot' sampling, together with measurements of total flow made indirectly by reference to markers, gives more variable results than can be obtained with re-entrant cannulas which 
permit complete digesta collection. Although the effects on the digestive system of the pig of inlying cannulas, the severed nerves around the cannulas and the method of collecting and returning digesta are not known, this remains the best method to study digestion. Unless otherwise stated, results in this review are from studies using re-entrant cannulas.

Absorption can be measured by gut cannulation, or by sampling blood to monitor changes in nutrient concentration after feeding. This can be done in conjunction with measurements of the blood flow-rate in the hepatic portal vein of the pig using isotope dilution (Braude, Cutts, Myres \& Porter, 1970), an electromagnetic probe (Rérat, 1971), marker dilution (Anderson, 1974), or thermal dilution methods (White, Webster, Farrell \& Jones, 1974). These are promising methods for measurement of absorption but appear to need further refinement before reliable, quantitative results are obtainable. A wide range of other methods for studying digestion and absorption was reviewed by Laplace (1972).

\section{Endogenous secretions}

Most studies of digestion and absorption pay inadequate attention to the endogenous secretions into the gut, despite the fact that they may lead to false interpretations about the stage of digestion of dietary components within the digesta, because of the major difficulties in their measurement. An over-all quantitative picture of endogenous secretion in pigs of a similar age and on a standard diet is needed. At present very limited evidence, often from work using experimental methods requiring further development, is available, for pigs of diverse age and given many types of diet, in the following: parotid saliva (Arkhipovets, 1956, 1962; Kvasnitskii \& Konyukhova, 1958); oesophageal wall (Pospeev, 1956); gastric juice (Kvasnitskii, r 95 I); bile (Auffray, Martinet \& Rérat, 1967); pancreas (Tkachev, Smirnov, Pasechnik \& Pakhno, 1970; Corring, Aumaitre \& Rérat, 1 972), and intestinal wall juices (Horszczaruk, Buraczewska \& Buraczewski, 1974). Much more information is required before correction of nutrient digestibility values for specific endogenous secretions can be made with confidence. The factors influencing the quantity and nature of these secretions under practical conditions and how they affect digestion and absorption merit further study.

\section{Digestion and absorption}

Unless otherwise stated all digestion and absorption values given are 'apparent', i.e. not corrected for endogenous secretions.

Carbohydrates. In a study using isolated loops of small intestine, Kvasnitskii (195I) found that pigs 6-9 months of age were able to absorb much larger amounts of glucose than such animals normally receive (in the form of starch). He also found that 0.45 of the starch in a cereal diet was hydrolysed in the stomach and duodenum and 0.19 of the intake was absorbed in this region in one pig. In another study this author studied starch and total carbohydrate digestibilities: 
these were 0.85 and 0.84 respectively anterior to the terminal ileum, and 0.09 and 0. I I respectively in the large intestine. The following ileal digestibility values were obtained by Cunningham, Friend \& Nicholson ( $\mathrm{I}_{963}$ ) in two pigs given small meals of simple composition: glucose 0.99 , maize starch 0.98 , galactose 0.95 , sucrose 0.95 , lactose 0.60 and potato starch 0.44 . The low value for lactose appeared to be caused by lactase ( $\beta$-galactosidase; $E C$ 3.2.1.23) deficiency. Keys \& DeBarthe $(1974 a, b)$ studied carbohydrate digestion in pigs with simple cannulas; they found $0.45-0.75$ of dietary starch was digested in the stomach, and variable amounts of hemicellulose and cellulose digestion. Horszczaruk $(1971 b)$ found that $0.36,0.63$, 0.71 and 0.80 of carbohydrate from a cereal diet was digested and absorbed in the proximal, central and distal one-thirds of the small intestine and in the caecum respectively in slaughtered pigs, and $0.83,0.87$ and 0.90 anterior to the caecum, colon and rectum of pigs with simple cannulas on similar diets (Horszczaruk, 1971a).

The digestion of molasses was studied by Ly (1971). The activity of amylase in the pancreatic juice of growing pigs was discussed by Corring et al. (1972). The age and site distribution of mucosal carbohydrases were studied by Manners \& Stevens (1972) using slaughtered pigs.

By means of continuous measurement of hepatic portal vein blood-flow and glucose concentrations, Rérat \& Aumaitre (1971) found that only 0.08 of a small starch meal was absorbed within I h and 0.60 within $7 \mathrm{~h}$. Subsequently, Rérat, Février, Aumaitre, Vaissade \& Vaugelade (r973) found that dietary free glucose was more rapidly absorbed than glucose from starch, and Rérat, Aumaitre, Vaugelade \& Vaissade (1974) showed that there was a slight decrease in the amount of glucose absorption from a starch meal as the intake rose.

The digestion and absorption of crude fibre was found to be $0.05,0.13$ and 0.26 anterior to the caecum, colon and rectum of four pigs with simple cannulas by Horszczaruk (1971a); however, in a slaughter trial Horszczaruk (1971 $b$ ) found little evidence of fibre digestion but signs of increased fibre in the stomach and the large intestine, probably both due to microbial and mucosal cell fractions contributing to the determined fibre. Horszczaruk \& Sljivovacki (1966, I97I) found that digestion and absorption of purified cellulose or lucerne meal suspended 2 or 4 $\mathrm{d}$ in silk bags in the digestive tract occurred mainly in the caecum rather than the colon, and that this process was more extensive in 18 -month-old than 4-month-old pigs; the maximum values obtained were 0.70 and 0.95 for purified cellulose and 0.30 and 0.35 for lucerne-meal cellulose in 2 and $4 \mathrm{~d}$ respectively. Braude, Low, Partridge \& Sambrook (1975) found evidence of fibre digestion and absorption in the large intestine of pigs given purified cellulose but not those given a cereal diet; it is possible that digestion and absorption were balanced by microbial synthesis in the latter instance. Microbiological studies are clearly needed to resolve some of the outstanding problems in this area.

Fat. It has been shown that pigs absorbed micellar fat from an isolated loop of small intestine much more rapidly than the rate at which fat in digesta from a diet containing $100 \mathrm{~g} \mathrm{fat} / \mathrm{kg}$ reached the loop, and that the ability of pigs to absorb emulsified fat was very limited (Freeman, Noakes, Annison \& Hill, 1968). 
Cunningham et al. ( 1963 ) found that 0.80 of maize oil and beef tallow were absorbed anterior to the ileum of two pigs with re-entrant cannulas, while Braude et al. (1975) found a corresponding value of 0.89 for maize oil. Horszczaruk $($ I $971 a, b)$ found that only $0.40-0.50$ of cereal-diet fat was absorbed anterior to the colon and $0.50-0.60$ in the whole gut; in his work the slaughter method and simple cannulas were used.

The secretion of lipase (EC 3.1.1.3) was studied by Corring et al. (1972).

Minerals. Major endogenous addition of minerals to the anterior gut has been noted by Horszczaruk (1971 $b, c)$ and Braude, Low, Partridge \& Sambrook (1973); the same authors have noted the importance of the large intestine in mineral absorption, in contrast to Kvasnitskii (1951), who found excretion into the large intestine. Partridge (1975) found that the large intestine was responsible for the absorption of one-third of the calcium, most of the magnesium and sodium, and some potassium and phosphorus in the two diets he used. The apparent absorption of zinc, copper and manganese in the small intestine of two pigs was found to be $0.60,0.40$ and 0.20 respectively by Savic \& Zebrowska (1972). The kinetics of digestion and absorption of $\mathbf{P}$ (using ${ }^{32} \mathrm{P}$ ) were studied by Gueguen, Besançon \& Rèrat (1968) using balance and blood-sampling methods.

Water. All studies with simple or re-entrant cannulas in the anterior small intestine have shown that there was two to four times more water flow in $24 \mathrm{~h}$ in this region than was ingested in $24 \mathrm{~h}$. In most instances the average concentration of dry matter in digesta from cereal diets was maintained at about $100 \mathrm{~g} / \mathrm{kg}$ digesta, but diets with a high solute concentration have given rise to digesta of very low dry matter content. Although Braude et al. (1975) found that most of the net absorption of dietary water from a cereal diet occurred in the large intestine, and most of that from a purified diet occurred in the small intestine, this ignores the fact that much more water is always absorbed by the small intestine than by the large intestine, because of endogenous secretions.

Protein. The amount of $\mathrm{N}$ passing the duodenum of pigs with re-entrant cannulas has been found to be about the same as intake by Kvasnitskii (195I), Holmes, Bayley \& Horney (1974) and Low (unpublished results), while Horszczaruk (1971c) and Zebrowska \& Buraczewska (1972a) found 5-7 g more N than that ingested (irrespective of the protein content of the diets used), and Keys \& DeBarthe $(1974 b)$ found over $40 \%$ more than ingested using simple cannulas. The reason for this discrepancy is unclear. However, authors were agreed that $35-50 \%$ of the $\mathrm{N}$ in the duodenum was of non-protein form, indicating that extensive peptic hydrolysis occurred. A similar ratio of non-protein- $\mathrm{N}$ :total $\mathrm{N}$ has been found in other parts of the small intestine. Zebrowska, Buraczewska, Buraczewski \& Horszczaruk (1975) found that the most extensive absorption of $\mathrm{N}$ occurs in the middle one-third of the small intestine. The apparent digestibility of $\mathbf{N}$ in a wide range of proteins in the small intestine was measured by Zebrowska (1973a). Kvasnitskii (195I), Holmes, Bayley \& Horney (1973) and Braude et al. (1975) all showed that the role of the large intestine in digestion and absorption of $\mathbf{N}$ was very limited. Zebrowska (1973c) found that while intact casein given orally, or enzymically hydrolysed casein infused into the duodenum, were normally 
utilized, enzymically hydrolysed casein infused into the terminal ileum of pigs on a protein-free diet was decomposed and absorbed in the large intestine and then rapidly and almost completely excreted in the urine, while the pigs remained in negative $\mathbf{N}$ balance. This work suggests that changes in the amount or nature of nitrogenous compounds during transit through the large intestine are probably of little nutritional significance.

The digestion and absorption of protein in terms of amino acids has been investigated by Zebrowska \& Buraczewska (1972b), Zebrowska (1973b), Holmes, Bayley, Leadbeater \& Horney (1974), Buraczewska, Buraczewski \& Zebrowska (1975) and Low (unpublished results). While the general pattern of amino acid absorption followed that of $\mathrm{N}$, it was often noted that glycine, and to a lesser extent proline, formed a higher proportion of digesta than of dietary amino acids. Phenylalanine, tyrosine and leucine were among the most rapidly absorbed amino acids in the anterior small intestine, and the non-essential amino acids tended to be absorbed more slowly in this region. The range of absorption values for amino acids was large in the jejunum, and the values were influenced to a considerable extent by the nature of the protein (Zebrowska, 1973b).

The digestibility of amino acids has been frequently measured in faeces, and more recently in ileal digesta also (Bayley, Cho \& Holmes, 1974; Holmes, Bayley, Leadbeater \& Horney, 1974; Low, 1975). These studies showed that for most amino acids, the faecal digestibility value was slightly higher than the ileal value; however there was evidence of microbial synthesis of certain amino acids (particularly methionine). The study on amino acid infusion into the terminal ileum by Zebrowska ( $1973 \mathrm{C}$ ) already referred to indicates that ileal digestibility values are more reliable guides to the nutritional value of proteins than those from faeces.

The secretion of pepsin (EC 3.4.23.1) was studied in pigs with gastric pouches by Kvasnitskii (195I) and in the duodenum by Low (unpublished results). Corring \& Saucier (1972) measured changes in the secretion of trypsin (EC 3.4.21.4) and chymotrypsin ( $E C$ 3.4.2 I.I) in response to dietary $\mathrm{N}$ changes.

The fundamental question of how the supply of amino acids to meet the balance required in protein synthesis for lean meat production is influenced inter alia by dietary protein structure, nutrient interrelationships and the processes of digestion and absorption remains largely unanswered. Investigations to date have measured a relatively small number of the factors involved, and inter-nutrient and intersystem relationships have been little studied. Large differences in diet composition, level of feeding, and methods of sample collection, together with the often very small number of pigs used and their highly variable nature allow little more than generalized statements to be made about digestion and absorption at present. The prospects for advances along the lines mentioned seem good, and improvements in the efficiency of meat production as a result of greater understanding should be forthcoming once the relationship of digestion and absorption to liver and muscle metabolism is understood more clearly. 


\section{REFERENCES}

Anderson, D. M. (1 974). Proc. Nutr. Soc. 33, 30A.

Arkhipovets, A. I. (1956). Firiol. Zh. SSSR 42, 882.

Arkhipovets, A. I. (1962). Fisiol. Zh. SSSR 48, 365.

Auffray, P., Martinet, J. \& Rérat, A. (1967). Annls Biol. anim. Biochim. Biophys. 7, 261.

Badawy, A. M. (1964). In The Role of the Gastrointestinal Tract in Protein Metabolism, p. 175 [H. N. Munro, editor]. Oxford: Blackwell Scientific Publications.

Bayley, H. S., Cho, C. Y. \& Holmes, J. H. G. (1974). Fedn Proc. Fedn Am. Socs exp. Biol. 33, 94. Braude, R., Cutts, I. R., Myres, A. W. \& Porter, J. W. G. (1970). Proc. Nutr. Soc. 29, 60A.

Braude, R., Low, A. G., Partridge, I. G. \& Sambrook, I. E. (1973). Proc. Br. Soc. Anim. Prod. 2,85 .

Braude, R., Low, A. G., Partridge, I. G. \& Sambrook, I. E. (1975). Proc. Nutr. Soc. 34, 46 A.

Buraczewska, L., Buraczewski, S. \& Zebrowska, T. (1975). Roczn. Nauk roln. Ser. B $97,103$. Corring, T., Aumaitre, A. \& Rérat, A. (1972). Annls Biol. anim. Biochim. Biophys. 12, 109.

Corring, T. \& Saucier, R. (1972). Annls Biol. anim. Biochim. Biophys. 12, 233.

Crocker, B. F. \& Markowitz, J. (1936). Am. J. Physiol. I16, 33.

Cunningham, H. M., Friend, D. W. \& Nicholson, J. W. G. (1963). Can. Y. Anim. Sci. 43, 215.

Freeman, C. P., Noakes, D. E., Annison, E. F. \& Hill, K. J. (1968). Br. F. Nutr. $22,739$.

Guéguen, L., Besançon, P. \& Rérat, A. (1 968). Annls Biol. anim. Biochim. Biophys. 8, 273.

Holmes, J. H. G., Bayley, H. S. \& Horney, F. D. (I973). Br. F. Nutr. 30, 401.

Holmes, J. H. G., Bayley, H. S. \& Horney, F. D. (I974). Br. F. Nutr. 32, 639.

Holmes, J. H. G., Bayley, H. S., Leadbeater, P. A. \& Homey, F. D. (1974). Br. J. Nutr. 32, 479.

Horszczaruk, F. (1971a). Biul. Inst. Genet. Hodow. Zwiers. pol. Akad. Nauk. no. 21 , p. 101.

Horszczaruk, F. (197 I b). Biul. Inst. Genet. Hodow. Zwierx. pol. Akad. Nauk. no. 21, p. 17.

Horszczaruk, F. (197I c). Biul. Inst. Genet. Hodow. Zwierz. pol. Akad. Nauk. no. 21 , p. 137.

Horszczaruk, F., Buraczewska, L. \& Buraczewski, S. (1974). Rocsn. Nauk roln. Ser. B $95,69$.

Horszczaruk, F. \& Sljivovacki, K. (1966). Rocxn. Nauk roln. Ser. B 89, 67.

Horszczaruk, F. \& Sljivovacki, K. (I97I). Rocrn. Nauk roln. Ser. B 93, 143.

Keys, J. E. \& DeBarthe, J. V. (1974a). J. Anim. Sci. 39, 53.

Keys, J. E. \& DeBarthe, J. V. (1974b). Y. Anim. Sci. 39, 57.

Kvasnitskii, A. V. (195I). Voprosȳ Fiziologii Pishchevarenija u Svinei. Moscow: Sel'Khozgiz. (Translated by D. E. Kidder).

Kvasnitskii, A. V. \& Konyukhova, V. A. (1958). Fixiol. Zh. SSSR 44, 590.

Laplace, J. P. (1972). Annls Zootech. $21,83$.

Low, A. G. (1975). Proc. Nutr. Soc. 34, 94A.

Ly, J. (I97I). Reota cub. Cienc. agric. 5,351 .

Manners, M. J. \& Stevens, J. A. (1972). Br. F. Nutr. 28, I I 3.

National Research Council (1969). Publs natn. Res. Coun., Wash. no. I684.

Partridge, I. G. (1975). Proc. Nutr. Soc. 34, 47A.

Pospeev, F. A. (1956). Trudy bashkir. sel'.-khoz. Inst. 7, 249.

Rérat, A. (1971). Annls Biol. anim. Biochim. Biophys. 11, 175.

Rerat, A. \& Aumaitre, A. (1971). Proc. xıth int. Congr. Anim. Prod., Versailles 2, 6.

Rerat, A., Aumaitre, A., Vaugelade, P. \& Vaissade, P. (1974). Proc. Nutr. Soc. 33, 102 A.

Rerat, A., Fevrier, C., Aumaitre, A., Vaissade, P. \& Vaugelade, P. (1973). Cah. Nutr. Dièt. 8, I54. Savic, S. \& Zebrowska, T. (1972). Zborn. Rad. Inst. Stotar., Novi Sad $5,43$.

Tkachev, E. V., Smirnov, O. K., Pasechnik, A. P. \& Pakhno, V. S. (1970). Sb. nauch. Rab. vses. nauchno-issled. Inst. Zhieot. 20, 28.

White, F., Webster, A. J. F., Farrell, D. J. \& Jones, A. S. (1974). Proc. Nutr. Soc. 33, 3IA.

Zebrowska, T. (1973a). Rocrn. Nauk roln. Ser. B 95, I 5 .

Zebrowska, T. (1973b). Rocan. Nauk roln. Ser. B 95, 135.

Zebrowska, T. (1973c). Rocsn. Nauk roln. Ser. B 95,85 .

Zebrowska, T. \& Buraczewska, L. (1972a). Roczn. Nauk roln. Ser. B 94, 81 .

Zebrowska, T. \& Buraczewska, L. (1972b). Rocsn. Nauk roln. Ser. B 94, 97.

Zebrowska, T., Buraczewska, L., Buraczewski, S. \& Horszczaruk, F. (1975). Rocsn. Nauk roln. Ser. B $96,79$. 